\title{
International Deaf Contributions for Scientific Research: Giving Access to Brazilian Deaf and Hearing Communities
}

\author{
Fabiola V. Saudan ${ }^{1,2}$, Nuccia N. T. De Cicco², Osilene M. S. S. Cruz ${ }^{1}$, \\ Gustavo Henrique Varela Saturnino Alves ${ }^{3}$, Helena C. Castro ${ }^{1,3^{*}}$ \\ ${ }^{1}$ Professional Master Course in Diversity and Inclusion, CMPDI, UFF, Niterói, Brazil \\ ${ }^{2}$ Post-Graduation Program in Science and Biotechnology, PPBI, UFF, Niterói, Brazil \\ ${ }^{3}$ Post-Graduation Program in Sciences, Technologies and Inclusion, PGCTIn, UFF, Niterói, Brazil \\ Email: ^hcastro@id.uff.br, ^hcastrorangel@yahoo.com.br
}

How to cite this paper: Saudan, F. V., De Cicco, N. N. T., Cruz, O. M. S. S., Alves, G. H. V. S., \& Castro, H. C. (2021). International Deaf Contributions for Scientific Research: Giving Access to Brazilian Deaf and Hearing Communities. Creative Education, 12, 1192-1206.

https://doi.org/10.4236/ce.2021.125089

Received: January 10, 2021

Accepted: May 28, 2021

Published: May 31, 2021

Copyright $\odot 2021$ by author(s) and Scientific Research Publishing Inc. This work is licensed under the Creative Commons Attribution International License (CC BY 4.0).

http://creativecommons.org/licenses/by/4.0/

\begin{abstract}
Brazilian deaf students choose careers mainly from the areas of social sciences. Apparently this is associated with the lack of content in Brazilian Sign Language about scientific and technological areas or even due to the lack of knowledge about deaf professionals and/or scientists working in these areas. Thus, this work aimed to translate to Portuguese and evaluate an American website called "Deaf Scientist Corner" dedicated to publicizing deaf scientists and their achievements, followed by evaluation. The translated site in Portuguese is "O Canto do Cientista Surdo" that was evaluated by 35 people including deaf ones. The results showed great acceptance, and potential to motivate so that the deaf can be inspired by scientific and technological careers. This site can also strength and disseminates these workplaces to the deaf in the society. Therefore, this website translation analysis reinforced that the knowledge about deaf scientists has great potential to encourage deaf people to continue in technological and scientific areas.
\end{abstract}

\section{Keywords}

Web Accessibility, Science and Media, Social Inclusion, Deaf Scientist, Inclusive Science Education

\section{Introduction}

In order to fully and better experience technology that is present in our life constantly, the society should understand science (Porter, 2014; Fischhoff \& Scheufele, 2014; Burns \& Medvecky, 2018; Alves et al. 2020). The literature reports 
about difficult on this understanding for most of population worldwide (Castelfranchi et al., 2013; Dudo \& Besley 2016; Burns \& Medvecky, 2018; Reincke, Bredenoord, \& van Mil 2020), but this is aggravated in the case of deaf community that has little access, especially in Sign language (Rose, 2020; Castro et al., 2020). In Brazil, when it comes to international data, the scenario is even worse (Almeida, Schiaffino, \& Rumjanek, 2014; De Cicco, 2016; Silva et al., 2020). It is clear that there is a communicative barrier between deaf and listeners regarding the language of scientific communication, especially involving biological and technological data (Reis, 2015; Rosa 2015).

Currently, there are about 10 million of deaf and hard of hearing in Brazil but only $10 \%$ of this population is included in the scholar system (IBGE, 2010; INEP, 2015). Despite the Brazilian law 13.146/2015 that states the use of Brazilian Sign Language (Libras, BSL) as the first language of deaf community, and Portuguese as their second one for teaching purpose, this is still not assured in the most states of the country (Cruz \& Alves, 2016; Dias et al., 2014; Brasil, 2002, 2015). Compared to hearing students, the education of Brazilian deaf students is less efficient since the bilingual teaching is still not fully accomplished and/or available to the whole deaf community (Smith \& Allman, 2010).

In addition to this complex teaching scenario, since Libras/BSL is a young language, there are not enough scientific signals to report the whole richness and complexity of biological and technological topics, still missing glossaries and dictionaries in BSL (Smith \& Allman, 2010; Dias et al., 2014).

The absence of national academic signs makes even more difficult to understand these contents as they are 1) presented using dactylology; and/or 2) significantly reduced; and/or 3) have their complexity resumed; and/or 4) new signs are created without a national standardization, which is even worse (Dias et al., 2014). This is not a problem exclusive of Brazil as many countries with great scientific development also report the same issues. This led to the emergence researchers and development groups of glossaries and dictionaries (Barral \& Rumjanek, 2018).

It is important to mention that it is not enough to have a sign for the topics but the analogous meaning is also expected somehow. An environment focused on study and research the specific biological or technological topic is better for the appearance of new and meaningful signs. Therefore, the participation of deaf researchers on these specific areas may increase and improve BSL. Unfortunately, Brazilian deafs with a doctorate degree $(\mathrm{PhD})$ in technological, biological or health sciences areas are rare. According to the literature, not only the accessibility of the contents in sign language, but also psychological and even financial issues to pay an interpreter, is among the reasons of choosing the social instead the technological area (Mori \& Sander, 2015).

In science education, the content should not only use the sign language as main language of instruction, but also visual strategies (Campello, 2008; Cruz \& Alves, 2016). It is also important to encourage critical thinking on this public together with practical experiments, similar to what is proposed to the hearing 
students (Pinto-Silva, Martins, \& Rumjanek, 2013).

This scenario reveals the difficulties to deaf education regarding scientific area. The schools are the strongest and main link between scientific research and popular dissemination, but currently the scientific content also reaches students through internet, and social media on the cellphone, tablets and computers (Hsu, 2004; Kastrup, 2000). Importantly, the internet lowered the differences between deaf and listeners as they both may use the internet to establish social relationships and to seek important information to their academic life. The visual resources, such as graphics and images, animation and videos, contributes to the wide access of deaf people to these contents although the language is still the most important barrier (Rosa \& Cruz, 2001).

In addition, Rocha et al. (2020) emphasize that communicational accessibility is scarce at museums and science centers, and when it comes to translation resources for sign languages, these are almost nonexistent in the reality of Latin America, especially in Brazil. This affects the access to scientific information, especially those aimed at the general public but not accessible to the deaf community.

Considering the context of an inclusive scientific education, Brazilian deaf students should be able to find deaf people who contributed to science since it may increase their interest to these areas, as they value the identity and their performance in different fields of work (Santana \& Sofiato, 2017). However, there are enormous difficulties to find information about deaf scientists in portuguese and even in English. One exception is the website called the "Deaf Scientist Corner" (https://twu.edu/dsc). from the United States of America, where it is possible to find data about deaf scientists, whether in the humanities/social, technological or biological fields, all gathered in this website dedicated to the biographical dissemination of these famous deaf scientists.

The website was developed by Dr. Chad E. Smith (Texas Woman's University, Dexton, Texas, USA, https://twu.edu), and by the teacher Jennifer Borgman (Sherman Regional Day School Programs for the Deaf, Sherman, Texas, USA) (Smith \& Allman, 2010), based on different books including: 1) “A Biographical Dictionary: Deaf Persons in the Arts and Sciences”, published in 1995 by Lang e Meath-Lang; 2) "Silence of the Spheres: The Deaf Experience in the History of Science", published in 1994 by Lang; 3) "The New York Public Library Science Desk Reference", published by Barnes-Svarney in 1995. Since deaf culture reinforced the importance of the "visual experience" (Strobel, 2009), everything showed on this website is developed in the most visual and colorful way possible.

Considering that, the scientific content in science education should not only use sign language as main language of instruction, but also include visual strategies (Campello, 2008; Cruz \& Alves, 2016) and encourage critical thinking on this public, similar to what is proposed to the hearing students (Pinto-Silva, Martins, \& Rumjanek, 2013). Thus, the translation of this website can be a promising way to awaken and maintain interest, especially with regard to deaf celebrities who impacted the development of scientific and technological know- 
ledge.

Therefore, the aim of this work was to allow the access of Brazilian deaf and hearing people to the information about deaf researcher contributions showed by the "Deaf Scientist Corner" website by translating it to Portuguese. In this work we also evaluated this translated site by deaf people, including professors and teachers of deaf students, interpreters and also professors with Master degree in Diversity and Inclusion of Federal Fluminense University of Brazil.

\section{Methods}

\section{Reconstructing and translating the website}

An intensive online search was performed to find sites about deaf scientific community, using the keywords: deaf, site, research, science, deaf scientist and deaf researcher, in English and in Portuguese.

The website "Deaf Scientist Corner" (https://www.twu.edu/dsc) was found in our survey and wasalsoreferred by a coworker, Dr Jean F. Andrews (Lamar University). This site was registered by Drs. Chad E. Smith (Texas Feminine University- https://twu.edu/) and Jennifer Borgman (Sherman Regional Day School Programs for the Deaf), who granted authorization for the translation of the full content of the site. They constructed the original site based on the books: 1) "A Biographical Dictionary: Deaf Persons in the Arts and Sciences", published in 1995 by Lang e Meath-Lang; 2) "Silence of the Spheres: The Deaf Experience in the History of Science", published in 1994 by Lang; 3) "The New York Public Library Science Desk Reference”, published by Barnes-Svarney in 1995. The site authors who granted authorization for the translation of the full content of the site.

The Brazilian translated site was initially constructed in Wix platform (https://pt.wix.com/, Wix.com, Inc, Gush Dan, Israel) using the Texas University website as a template. After translation, all information as well as pictures, colors and organization were reproduced identically. We decided to translate meanwhile only to Portuguese written form considering: 1) this is a Brazilian Language for both deaf and hearing people; 2) the avatar accessibility technology is considered by Deaf and hard of hearing still inadequate due to the absence of the facial expression, one of the main parameters of all sign languages worldwide (Sacks, 2010); 3) Brazilian sign language (BSL) has several signs for the same scientific term due to regionalism, which demand a selection of terms for translating the site for BSL (Amorim et al., 2020; Castro et al., 2020). However, most important, there is no searching program (eg. Google) capable of finding Brazilian Sign Language keywords. There is no such problem with Portuguese, thus allowing the translated site to be searched, found and consulted.

\section{Evaluating the translated website}

A questionnaire with 16 questions was constructed in a google formulary (Google forms) and sent by WhatsApp and email for more than 50 people including deaf people, professors and teachers of deaf students, and interpreters.

The questionnaire was composed of the following questions: 
1) What is your relationship with uff?

2) What's your profession?

3) Genre;

4) Age;

5) Do you have any special needs/disabilities? What?

In this section choose a grade from 0 - 10 to the following aspects;

6) The layout (visual) of the site;

7) Use of photographs;

8) Quantity of texts on the site;

9) Organization of the information;

10) Accessibility;

11) Does the site meet your expectations?

12) The final note for this site is;

13) Can the site well disseminate deaf researchers?

14) Do you know any website that promotes deaf researchers? Cite it;

15) Do you think this site is important and should be published? Why?

16) Write, if you want, any suggestions or comments to improve the site.

From the 50 submissions of the forms, we obtained a response from 35 volunteers (21 - 65 years old, 94\% women) answered including: deaf people (5), professors $(n=5)$ and teachers of deaf students $(n=20)$, and interpreters $(n=$ 3), among others. This study was executed as part of the extension program School of Inclusion of Federal Fluminense University.

\section{Results and Discussion}

\section{The translation to create the Brazilian website " $O$ Canto do Cientista-} Surdo"

Before our work, the site "Deaf Scientist Corner" was offered only in an English version, which prevented deaf community from knowing about famous scientists that they can admire and inspired by to choose scientific careers. The automatic translations (eg. Google) were not accurate and even more complicated, thus needing a careful and adapted translation to get comprehensive in other languages such as Portuguese.

The Brazilian website was constructed in the Wix platform (https://pt.wix.com) (Wix.com, Inc, Gush Dan, Israel) by using the same layout of colors and figures style of the American site (Figure 1). The platform allowed the construction of an exact copy of the American site, including distribution of pages and text, without changing its main features, maintaining its accessibility and intuitive profile for both deaf and hearing communities.

Therefore, the free hosting, easy access and use, as well as the simple aesthetics, allowed the creation of the Brazilian website version named " $O$ Canto do Cientista surdo", since "canto" means corner or convergence, a place where the searcher meet the deaf scientists (https://cientistasurdo.wixsite.com/inicio).

The initial translation was made by using internet translators as well as an expert 


\section{Deaf Scientist Corner}

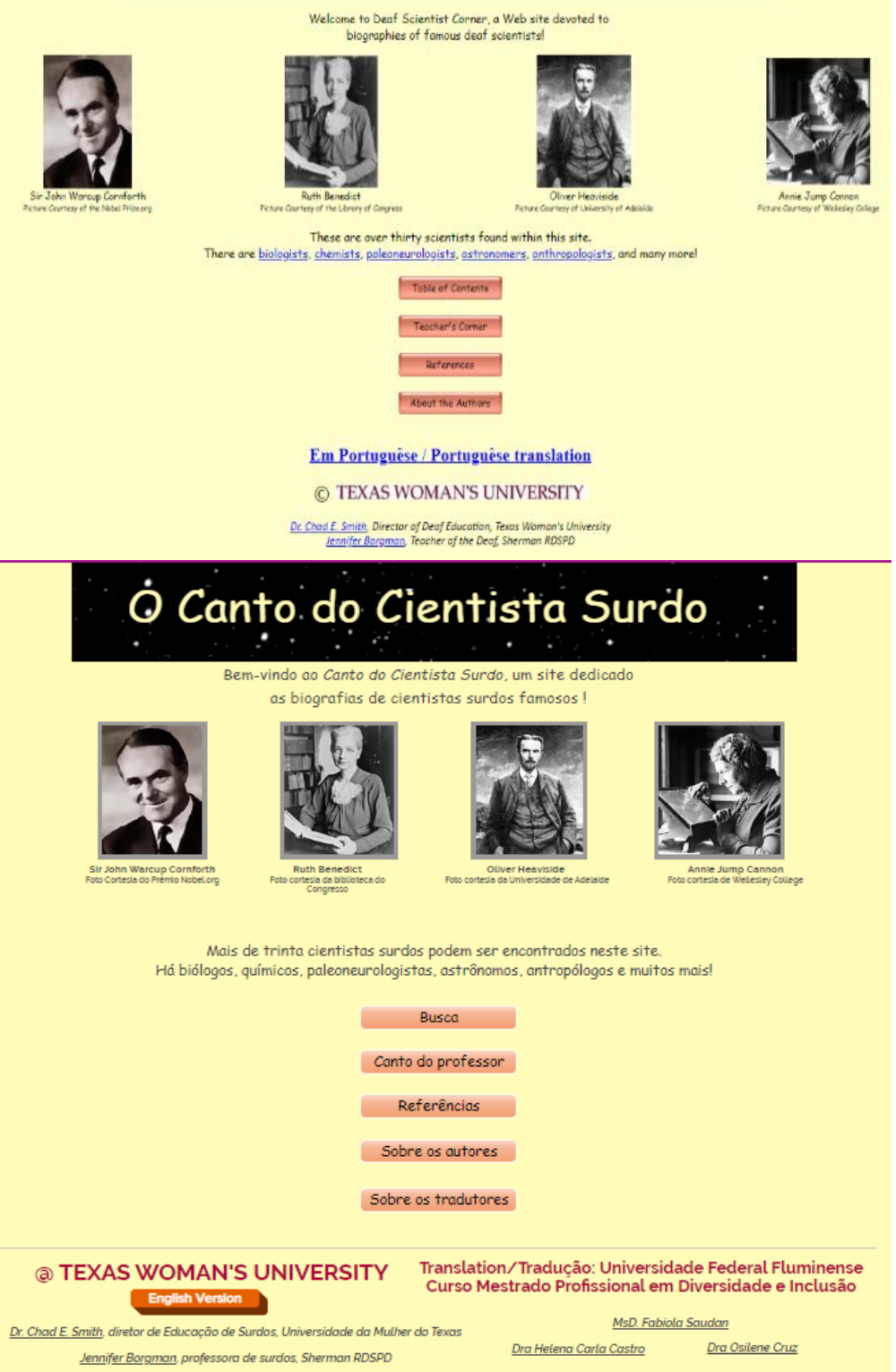

Figure 1. Comparison of the American "Deaf Scientist Corner" website (up) and its Brazilian version (down) translated from English to Portuguese, with linguistic adaptation.

in both English and Portuguese languages that was also consulted. All webpages of the "Deaf Scientist Corner" were translated, including those with the 35 deaf scientists descriptions and the 20 scientific areas with some adaptations (Figure 2 and Figure 3).

One question about the translation of this site that was raised by our group was: considering that the deaf person can learn a third foreign language such as English (Sousa, 2014), why translate this website? In fact, in Brazil it is more common to have access to English language offered to the hearing students, than to the deaf students, especially when it comes to the use of the Brazilian sign 


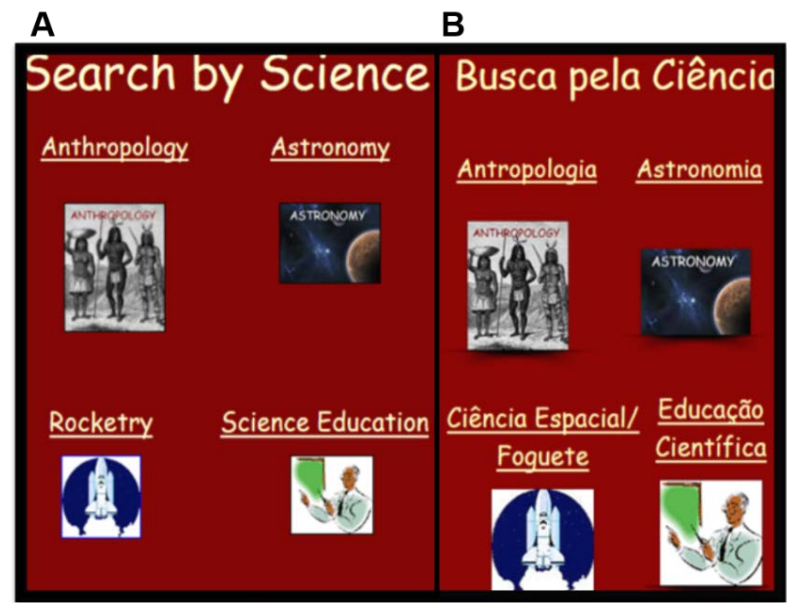

Figure 2. Example of adapted translation for the site "Deaf Scientist Corner". (A) original Site and (B) Brazilian version with linguistic adaptation on "Rocketry" (Source: author).
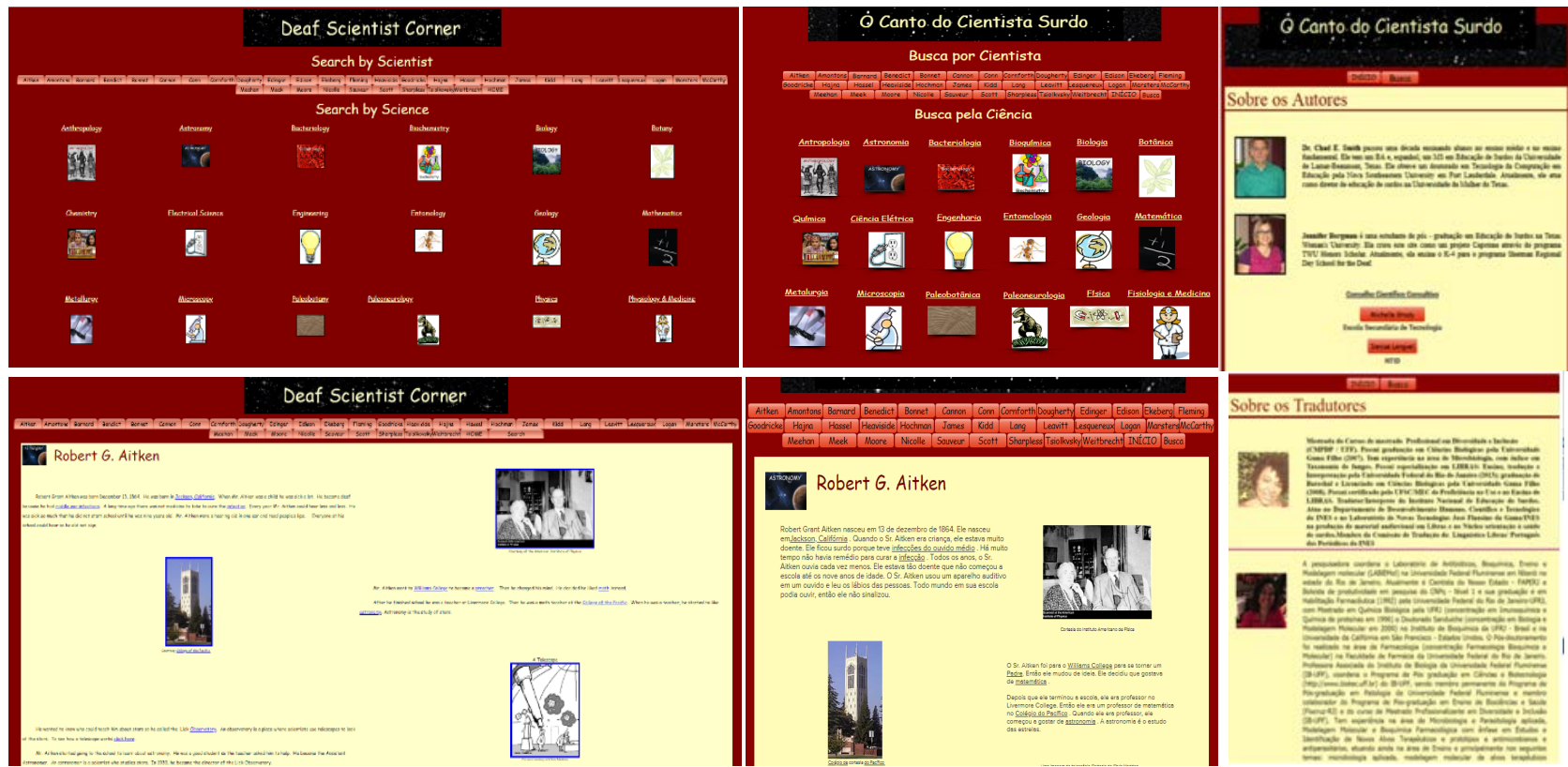

Figure 3. Comparison of the "Deaf Scientist Corner" website with its Brazilian version. On the Left (up and down), the original website page in English; On the center (up and down), the Brazilian version translated from English to Portuguese, with linguistic adaptation; On the Right (up and down), Pages added in Portuguese about the Authors; and Translators group (Source: author's production).

language as the teaching language. Thus, the access and fully understanding of the English language by Brazilian deaf people is extremely rare. Hence, creating a Portuguese version of the American website "Deaf Scientist Corner" is one important step to make science even more accessible for this community whereas also allows Brazilian hearing community that has no English skills to access as well. Thus, it is important to observe that the translated website is not to be used exclusively by deaf students as can be visited by Brazilian hearing people, helping them to know more about deaf researchers. Thus, this website may help to disqualify the myth that deaf community has a disability/deficiency that is a 
huge limitation that prevents them to full participate in the academic research scenario.

After translation, we obtained a site with 62 (sixty-two) translated pages (https://cientistasurdo.wixsite.com/inicio) containing the academic life of 35 (thirty-five) deaf scientists trained in different areas, including technological, humanities and biological areas, in a total of 20 (twenty) diverse areas. The only additions were about the relationship among this translation, the master degree of the main author of this article, and with the original site of Texas University, added in the index page (https://cientistasurdo.wixsite.com/inicio) as well as the addition about our translator group

(https://cientistasurdo.wixsite.com/inicio/sobre-os-tradutores).

Considering that the Brazilian Deaf students mostly have chosen post graduation degrees in Pedagogy, Sign language Literature and social sciences (Zillioto, Souza, \& Andrade, 2018; Monteiro, 2018; Mourao \& Karnopp, 2020), our website version allows to show in Portuguese that there are other interesting professional choices including Physics, Chemistry and even Rocket science. Thus, it can stimulate the deaf students to conquer and occupy other scientific profession spaces, encouraged by these Deaf scientists academic life.

In this work, the Brazilian website version was evaluated by using a Google form questionnaire applied to 35 volunteers including deaf people, professors and teacher of deaf students, and interpreters. Mostly of the volunteers were women (94\%) with 21 - 65 years old that had to select one evaluation note, from 1 (bad) to 10 (excellent) in the questionnaire to rate the site specific layout features.

The initial questions were about the visual organization of site, an important issue to the deaf and hard of hearing persons according to the literature (Campello, 2008; Barral \& Rumjanek, 2018). According to their answers, 91\% of volunteers considered the layout of the site from good to excellent (Figure 4(A)), which reinforced our decision on making no changes on the original layout.

The use of photos is another relevant point to deaf and hard of hearing persons as well as the limited use of written texts, and according to the volunteers, the site was approved by $97 \%$ (Figure $4(\mathrm{~B})$, Figure $4(\mathrm{C})$ ). The amount of texts was unanimously approved, with the evaluation from great to excellent, once again proving the translation adapted as the best strategy (Figure $4(\mathrm{C})$ ). Some authors discuss about text reduction on comprehension, but in the case of this website, the focus on the theme is necessary with clarity and direct purpose (De Quadros, 2003; Burnham et al., 2008).

In the organization and ease-to-find information, $100 \%$ of volunteers gave grade above of 6 , and $44 \%$ of them considered excellent (Figure 5(A)).

About the accessibility of the Brazilian site, $73 \%$ of volunteers selected grades from 8 to 10 (Figure $5(B)$ ). They pointed the absence of translation for sign language as a justification for the lowest grades. Some volunteers also suggested the use of audio-description of the images for better accessibility to blind and 


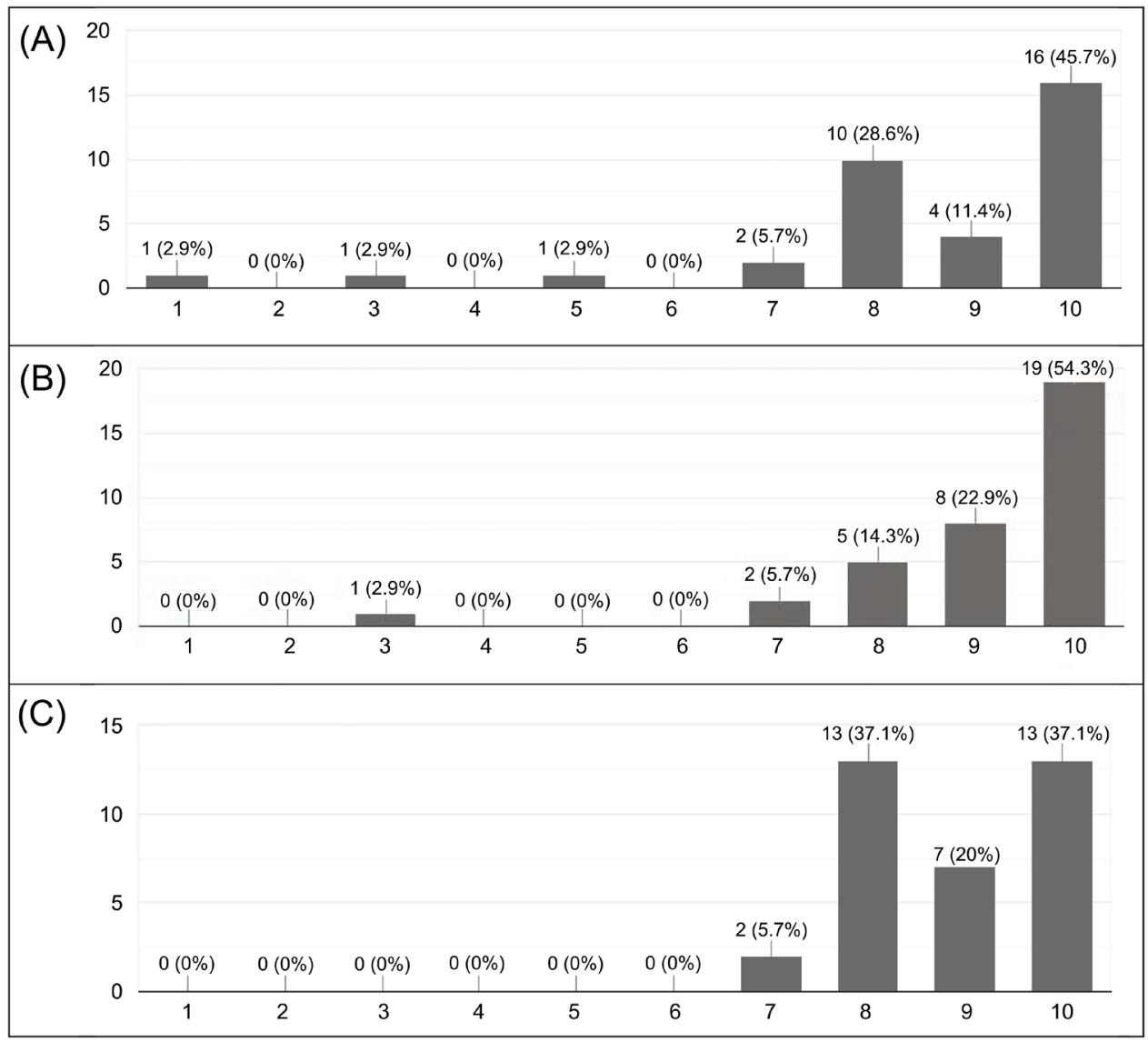

Figure 4. Evaluation (grades 1 - 10) of the Brazilian website version by 35 volunteers including deaf people, professors and teachers of deaf students, and interpreters. (A) Overall Layout; (B) Use of Photos; (C) Amount of Written Text (Source: author).

low vision users. The literature point that sign language material are more available in the internet (Stumpf, 2000). However, looking for any data through BSL online is still not feasible as there is no such platform on the internet for that yet. Therefore, the first attempt to use Portuguese for spreading the deaf researchers contributions is the most accessible way in the present moment in this work of translation.

Importantly, the majority approved the Brazilian site with final grade from 7 to $10(97 \%)$, stating that it meets their expectations (88\%) (Figure $5(C)$ and Figure 6(A)).

We also asked to the volunteers if they knew any website with divulgation of deaf researchers and more than $80 \%$ of the answers were negative (Figure $7(\mathrm{C})$ ). Despite the American website "Deaf Scientist Corner" being online for years, its divulgation in Brazil is very low, probably because it is in English which difficult the access to its content. It is important to consider that the original site from Texas University was never evaluated by the Brazilian public, whereas these answers confirmed that our Brazilian website version may occupy an open space, and it may increase the divulgation about the deaf scientist researchers for everyone, which is the purpose of both English and Brazilian version of this site. 


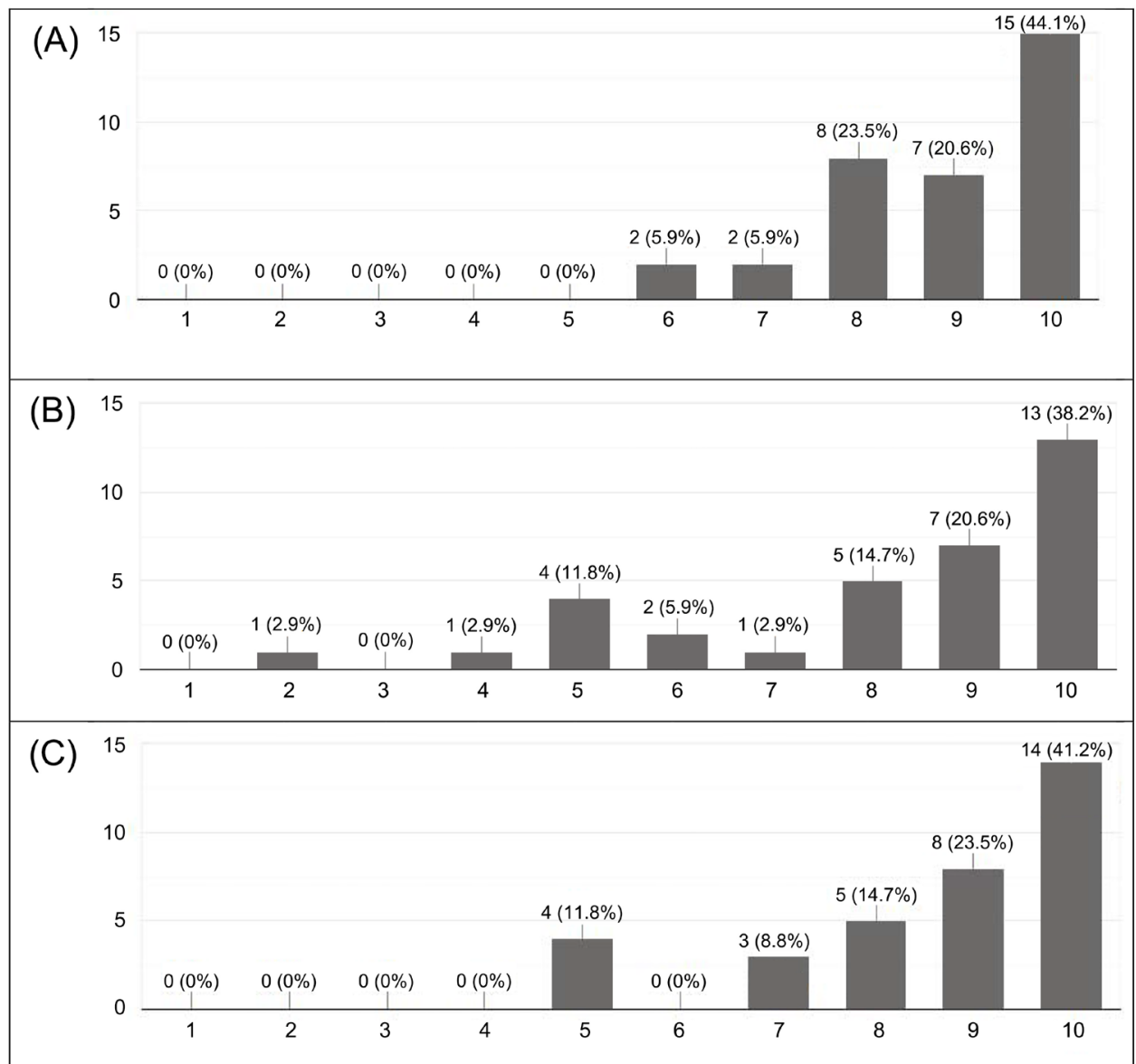

Figure 5. Evaluation (grades 1 - 10) of the Brazilian website version by deaf people, professors and teachers of deaf students, and interpreters ( $\mathrm{n}=35)$. (A) Organization; (B) Accessibility; (C) Meeting expectations (Source: author).

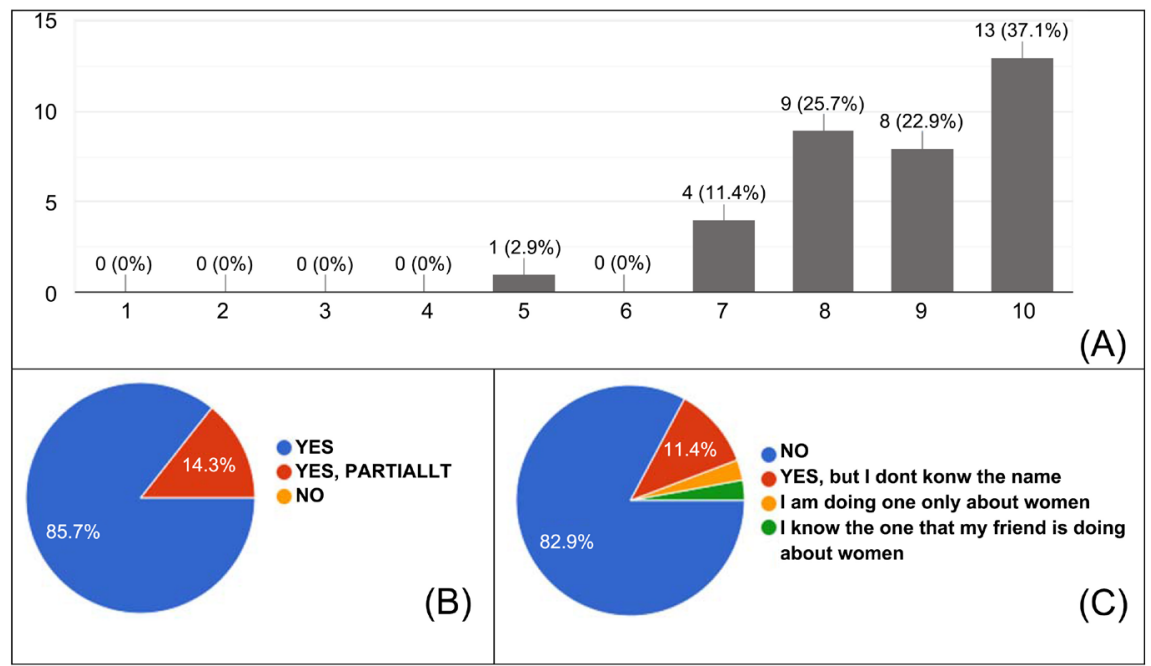

Figure 6. Evaluation of the Brazilian website version by deaf people, professors and teachers of deaf students, and interpreters $(n=35)$. They selected one evaluation note from 1 (bad) to 10 (excellent) to rate the site specific layout features. (A) Final grade for the site; (B) The Brazilian site version is able to divulgate deaf researchers properly; (C) Knowledge about other sites that divulgate deaf researchers (Source: author). 


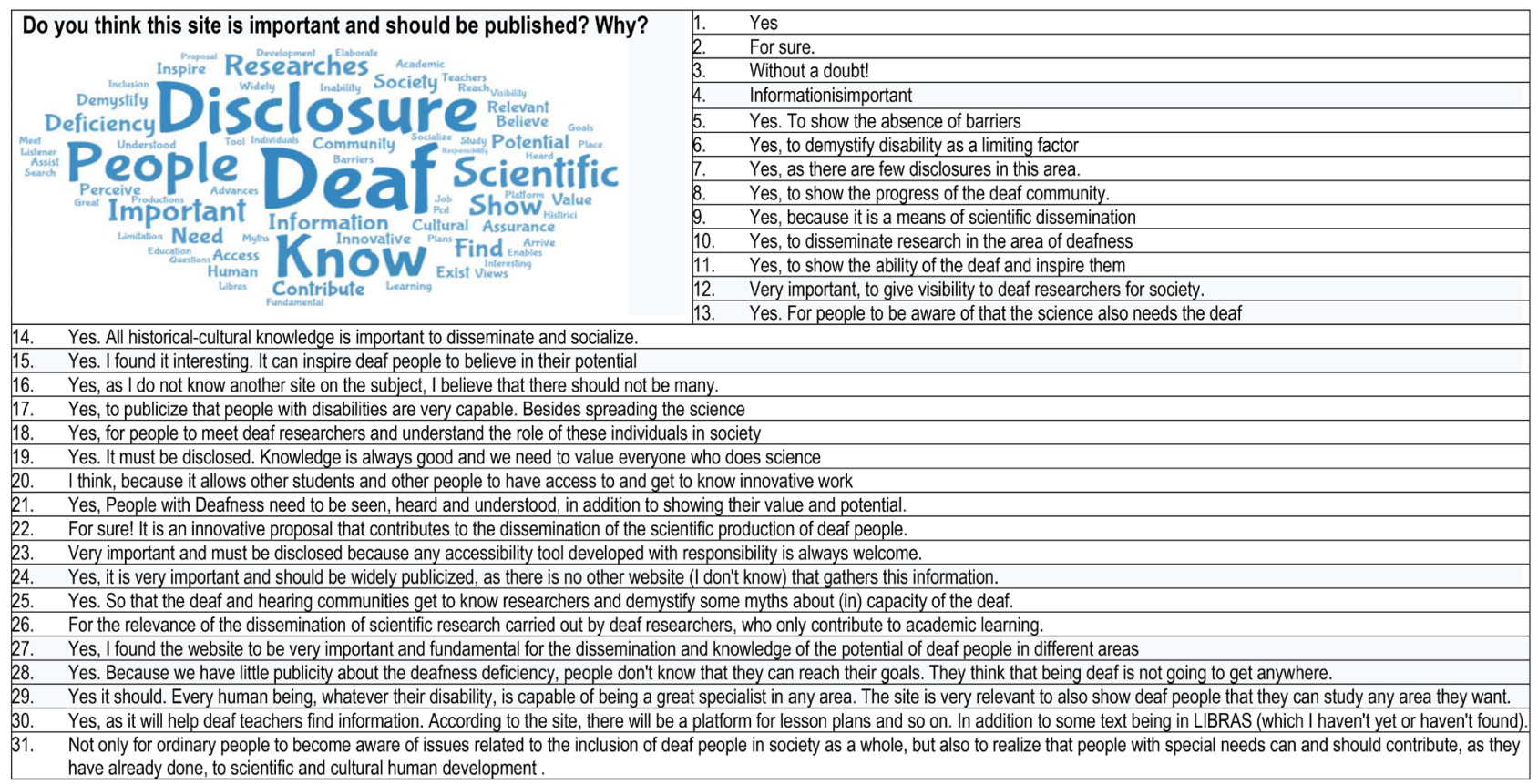

Figure 7. Evaluation of the Brazilian website version by deaf people, professors and teachers of deaf students, and interpreters ( $\mathrm{n}=$ 31). Answers for the question "Do you think this site is important and should be published? Why?". Inset. Analysis of the word frequency on their answers by using https://wordart.com/create.

Finally, we asked to the 35 volunteers if the Brazilian website version is important and why should it be published online. The answers were listed in Figure 7 and were analyzed according to the word frequency by using https://wordart.com/create.

Interestingly, Disclosure was the word most cited by the volunteers that answered the question "Do you think this site is important and should be published? Why?" pointing to the achievement of our purpose with the translation of the American site to Portuguese.

Our analysis also revealed that the Brazilian version site, according to the answers of these volunteers, is "important and fundamental for the dissemination and knowledge of the potential of deaf people in different areas". Answer regarding helping the teachers activity on participating on this dissemination was also present ("Yes, as it will help deaf teachers find information...") pointing the site as a tool to stimulate the youngest deaf student to the knowledge about technologies and professions/researches such as referred by the literature (Smith \& Allman, 2010; Pinto-Silva, Martins, \& Rumjanek, 2013; OECD, 2019).

The need for spreading the knowledge for deaf and hearing people about deaf professionals skills is also observed in the answers of these two volunteers: 1) "Because we have little publicity about the deafness deficiency, people don't know that they can reach their goals. They think that being deaf is not going to get anywhere"; and 2)... "to demystify disability as a limiting factor").

According Monteiro (2018), more and more deaf people search for master and $\mathrm{PhD}$ degrees, but social sciences are still the most preferred among all sciences (Monteiro, 2018; Mourao \& Karnopp, 2020). So more strategies have to 
be created to change this profile that may help not only the deaf community but also the whole society. Based on the fact that diversity is pointed as a factor for creativity and innovation, our society has a lot to gain with deaf researchers participation in the technological and biological areas (Fisher et al., 2019; Shatunova et al., 2019; Fisher et al., 2019).

\section{Conclusion}

The American website "Deaf Scientist Corner" specialized in the dissemination of 35 famous deaf researchers and their major contributions to science are now available in its Brazilian website version "O Canto do Cientista Surdo" and it is officially linked to the original site directly in their index/main page.

According to the volunteers that evaluated the site, it is really important as it shows and amplifies knowledge about famous deaf scientific researchers and their contributions to research worldwide in different areas of science. The website also makes academic-scientific words accessible, whereas helps to enrich the personal scientific dictionary of each one that access it. As the volunteers said "It can inspire deaf people to believe in their potential" ... whereas ... "publicize that people with disabilities are very capable, besides spreading the science".

Unfortunately, the translation of the content into Brazilian sign language was not possible, considering especially the programming difficulties and the specific signs of the scientific and technological areas. This gap demands new computational strategies that allow greater accessibility to the deaf.

Despite of that, the translation of the content in English into Portuguese (the second official language of the deaf in Brazil) certainly favour access and disseminates the culture and achievements of deaf scientists. This translation, even if in written language, can be considered as a practice for the internationalization of academic experiences of deaf people in scientific areas, with great motivating potential within the deaf community, regardless of the country.

Finally, it is worth mentioning that the main author of this work is a biologist, deaf, with a master's degree in Diversity and Inclusion, who intends to provide people, deaf or listeners, access to knowledge about deaf scientists and how much they have already contributed to humanity, although in "silent" way" until now.

\section{Financial Support}

This work was supported by FAPERJ, CNPq, CAPES and UFF.

\section{Acknowledgements}

We wish to express our gratitude to Mauro Thiago Santos Pereira de Oliveira and Edilene Teixeira (Interpreters) for excellent technical assistance. We also thank FAPERJ, CNPq, CAPES and UFF for the financial support.

\section{Author Contributions}

Conceived and designed the search: HCC. Performed the research: FVS. Ana- 
lyzed the data: FVS, NNTDC, OC, HCC. Wrote the paper: NNTDC, GA, HCC.

\section{Conflicts of Interest}

The authors declare no conflicts of interest regarding the publication of this paper.

\section{References}

Almeida, R. C. N., Schiaffino, R. S., \& Rumjanek, V. M. (2014). Access and Comprehension of Information by Profound Deaf Youngsters in Brazil. Journal of Media and Communication Studies, 6, 174-178. https://doi.org/10.5897/JMCS2014.0411

Alves, G. H. V. S., Fragel-Madeira, L., De Azeredo, T. V., Castro, H. C., Pereira, G. R., \& Coutinho-Silva, R. (2020). Low-Cost Scientific Exhibition: A Proposal to Promote Science Education. Creative Education, 11, 760-782. https://doi.org/10.4236/ce.2020.115055

Amorim, G., Ramos, A. S. L., de Castro Junior, G., de Souza Afonso, L., \& Castro, H. C. (2020). Coronavirus, Deafness and the Use of Different Signs of the Area in Health during a Period of Pandemic Time: Is That the Best Option to Do? Creative Education, 11, 573-580. https://doi.org/10.4236/ce.2020.114042

Barral, J., \& Rumjanek, V. M. (2018). Empréstimos linguísticos para sinais científicos na área de Biociências. Revista Espaço, 49, 55-70.

Brasil (2002). Lei n. 10. 436, de 24 de abril de 2002. Dispõe sobre a Língua Brasileira de Sinais-Libras. Regulamentada pelo Decreto n. 5. 626 de 22 de dezembro de 2005, publicadono Diário Oficial da União, Brasília, n. 246, p. 28-30, de 23 de dezembro, seção 1, 2005

Brasil (2015). Lei n. 13. 146, de 6 de julho de 2015. Institui a Lei Brasileira de Inclusão da Pessoa com Deficiência (Estatuto da Pessoa com Deficiência).

Burnham, D., Leigh, G., Noble, W., Jones, C., Tyler, M., Grebennikov, L., \& Varley, A. (2008). Parameters in Television Captioning for Deaf and Hard-of-Hearing Adults: Effects of Caption Rate versus Text Reduction on Comprehension. Journal of Deaf Studies and Deaf Education, 13, 391-404. https://doi.org/10.1093/deafed/enn003

Burns, M., \& Medvecky, F. (2018). The Disengaged in Science Communication: How Not to Count Audiences and Publics. Public Understanding of Science, 27, 118-130. https://doi.org/10.1177/0963662516678351

Campello, A. R. S. (2008). Aspectos da visualidade na educação de surdos. Tese (doutorado). Universidade Federal de Santa Catarina, Centro de Ciências da Educação. Programa de Pós-Graduação em Educação. http://repositorio.ufsc.br/xmlui/handle/123456789/91182

Castelfranchi, Y., Vilela, E. M., De Lima, L. B., De Castro Moreira, I., \& Massarani, L. (2013). Brazilian Opinions about Science and Technology: The Paradox of the Relation between Information and Attitudes. História, Ciências, Saúde-Manguinhos, 20, 1163-1183. https://doi.org/10.1590/S0104-59702013000400005

Castro, H. C., Ramos, A. S. L., Amorim, G., \& Ratcliffe, N. A. (2020). COVID-19: Don't Forget Deaf People. Nature, 579, 343. https://doi.org/10.1038/d41586-020-00782-2

Cruz, O. M. S. S., \& Alves, C. M. J. (2016). A literatura surda e a Libras como mediadoras para o ensino de língua portuguesa a aprendizes surdos. Linguagens and Cidadania, 18. https://doi.org/10.5902/1516849225725

De Cicco, N. (2016). Pérolas da minha surdez (1st ed.). Porto Alegre: Wwlivros Editora. 
De Quadros, R. M. (2003). Phrase Structure of Brazilian Sign Language. In Crosslinguistic Perspectives in Sign Language Research. Selected Papers from TISLR 2000 (pp. 141-162). Hamburg, Germany: Signum Press.

https://www.researchgate.net/profile/Ronice_Quadros/publication/228459159_Phrase_ Structure_of_Brazilian_Sign_Language/links/5487fe040cf289302e2ee700.pdf

Dias, L. et al. (2014). Deafness and the Educational Rights: A Brief Review through a Brazilian Perspective. Creative Education, 5, 491-500.

https://doi.org/10.4236/ce.2014.57058

Dudo, A., \& Besley, J. C. (2016). Scientists' Prioritization of Communication Objectives for Public Engagement. PLoS ONE, 11, e0148867. https://doi.org/10.1371/journal.pone.0148867

Fischhoff, B., \& Scheufele, D. A. (2014). The Science of Science Communication II. Proceedings of the National Academy of Sciences of the United States of America, 111, 13583-13584. https://doi.org/10.1073/pnas.1414635111

Fisher, A. J., Mendoza-Denton, R., Patt, C., Young, I., Eppig, A., Garrell, R. L. et al. (2019). Structure and Belonging: Pathways to Success for Underrepresented Minority and Women PhD Students in STEM Fields. PLoS ONE, 14, e0209279.

https://doi.org/10.1371/journal.pone.0209279

Hsu, Y. (2004). Using the Internet to Develop Students' Capacity for Scientific Inquiry. Journal of Educational Computing Research, 31, 137-161. https://doi.org/10.2190/HYX8-CK1A-FVU3-5Y5W

IBGE (2010). Características da população e dos domicílios: Resultados do universo. Instituto Brasileiro De Geografia E Estatística.

https://biblioteca.ibge.gov.br/visualizacao/periodicos/93/cd_2010_caracteristicas_popul acao_domicilios.pdf

INEP (2015). Resumo Técnico: Censo da Educação Superior 2015 (2nd ed.). Brasília: Instituto Nacional de Estudos e Pesquisas Educacionais Anísio Teixeira.

Kastrup, V. (2000). Novas tecnologias cognitivas: O obstáculo e a invenção. In N. M. C. Pellanda, \& E. C. Pellenda (Org.), Ciberespaço: Um hipertexto com Pierre Lévy (pp. 38-54). Porto Alegre: Artes e Ofício.

Monteiro, S. M. (2018). Mestres e Doutores Surdos: Sobre a Crescente Formação Especializada de Pessoas Surdas no Brasil. Revista Virtual de Cultura Surda, 23, 1-40.

Mori, N. N. R., \& Sander, R. E. (2015). História da educação de surdos no Brasil. Seminário De Pesquisa Ppe, Universidade Estadual de Maringá, PR.

Mourao, C. H. N., \& Karnopp, L. B. (2020). The Experiences of Literary Hands. Sign Language Studies, 20, 375-391. https://doi.org/10.1353/sls.2020.0015

OECD (2019). Education at a Glance 2019: OECD Indicators-Brazil. Organisation for Economic Co-Operation and Development. https://doi.org/10.1787/f8d7880d-en

Pinto-Silva, F. E., Martins, P. R. S., \& Rumjanek, V. M. (2013). Rousing Interest in Science among Secondary School Deaf Students. Scholarly Journal of Scientific Research and Essay (SJSRE), 2, 104-108.

Porter, J. E. (2014). Time to Speak Up for Research. Science, 344, 1207. https://doi.org/10.1126/science.1256929

Reincke, C. M., Bredenoord, A. L., \& van Mil, M. H. W. (2020). From Deficit to Dialogue in Science Communication. EMBO Reports, 21, e51278. https://doi.org/10.15252/embr.202051278

Reis, F. (2015). A docência na educação superior: Narrativas das diferenças políticas de 
sujeitos surdos. Tese (Doutorado em Educação), 2015, 278f. Uberlândia: Universidade Federal de Uberlândia-UFU.

Rocha, J. N., Massarani, L., Abreu, W. V. D., Inacio, L. G. B., \& Molenzani, A. O. (2020). Investigating Accessibility in Latin American Science Museums and Centers. Anais da Academia Brasileira de Ciências, 92, e20191156. https://doi.org/10.1590/0001-3765202020191156

Rosa, A. S., \& Cruz, C. C. (2001). Internet: Fator de inclusão da pessoa surda. Revista Online da Biblioteca Prof. Joel Martins, 2, 38-54. https://doi.org/10.20396/etd.v2i3.580

Rosa, E. F. (2015). Surdos na pós-graduação. In $6^{\circ}$ Seminário Brasileiro de Estudos Culturais em Educação e $3^{\circ}$ Seminário Internacional de Estudos Culturais em Educação, jun 2015, Canoas, RS, Seminário.

Rose, B. (28th April 2020). Coronavirus: Lack of Sign Language Interpreters Leads to Legal Case against Government. BBC News. https://www.bbc.com/news/disability-52323854

Sacks, O. (2010). Vendo Vozes: Uma viagem ao mundo dos surdos. Tradução: Laura Teixeira Motta. São Paulo: Companhia das Letras.

Santana, R. S., \& Sofiato, C. G. (2017). Ensino de Ciências para estudantes surdos: Possibilidades e desafios. Revista Internacional de Formação de Professores, 2, 37-54.

Shatunova, O., Anisimova, T., Sabirova, F., \& Kalimullina, O. (2019). STEAM as an Innovative Educational Technology. Journal of Social Studies Education Research, 10, 131-144. https://jsser.org/index.php/jsser/article/view/916

Silva, A. G., Batista, T., Giraud, F., Giraud, A., Pinto-Silva, F. E., Barral, J., Guimarães, J. N., \& Rumjanek, V. M. (2020). Science Communication for the Deaf in the Pandemic Period: Absences and Pursuit of Information. Journal of Science Communication, 19, A05. https://doi.org/10.22323/2.19050205

Smith, C. E., \& Allman, T. (2010). Meeting the Challenges of Deaf Education Teacher Preparation: Innovative Practices in Online Learning. Journal of Online Learning and Teaching, 6, 523-532.

Sousa, A. N. (2014). Reflexões sobre as práticas de ensino de uma professora de inglês para surdos: A língua de sinais brasileira como mediadora do processo de ensino-aprendizagem. Revista Brasileira de Linguística Aplicada, 14, 1015-1044. https://doi.org/10.1590/1984-639820145706

Strobel, K. L. (2009). As imagens do outro sobre a cultura surda (2nd ed.). Florianópolis: Ed. da UFSC.

Stumpf, M. R. (2000). Língua de Sinais: Escrita dos surdos na Internet. In V Congresso Ibero-Americano de Informática na Educação (RIBIE). Vinadel Mar, Chile.

Zillioto, M. D., Souza, D. J., \& Andrade, F. I. (2018). Quando a inclusão não se efetiva: A evasão de alunos surdos ou com deficiência auditiva no ensino superior. Revista Educação Especial, 31, 727-740. https://doi.org/10.5902/1984686X28482 